\title{
Does Vitamin D Supplementation Reduce Cytokine Storm and Mortality in Geriatric Intensive Care Patients Diagnosed with COVID-19
}

\section{COVID-19 tanılı Geriatrik Yoğun Bakım Hastalarında D Vitamini Desteği Sitokin Fırtınasını ve Mortaliteyi Azaltır mı?}

\author{
(ㄱ) Yeliz Bilir1, (Akın Bilir 2, AAyten Saraçoğlu², ĐFulya Çiyiltepe1, (Elif Bombacı1, \\ Kemal Tolga Saraçoğlu', @Recep Demirhan ${ }^{3}$
}

'Health Sciences University, Kartal Dr .Lutfi Kirdar City Hospital, Department of Anesthesiology and Reanimasyon, Intensive Care Unit, Istanbul, Turkey 2Marmara University School of Medicine, Department of Anesthesiology And Reanimation, Istanbul, Turkey ${ }^{3}$ Health Sciences University, Kartal Dr. Lütfi Kırdar City Hospital, Department of Chest Surgery, Istanbul, Turkey

\begin{abstract}
Introduction: Coronavirus disease progresses from an asymptomatic stage to a fatal stage characterized by a cytokine storm. The present study aimed to emphasize the therapeutic effect of vitamin-D supplementation and its potential importance in reducing the disease severity in older adults in the intensive care unit after COVID-19 diagnosis.

Materials and Method: The data of 80 patients aged $\geq 65$ years who followed up in intensive care clinic. The inflammatory parameters and clinical course of 40 patients whose serum 25-hydroxyvitamin-D level was below $30 \mathrm{ng} / \mathrm{ml}$ and who received vitamin-D supplementation (case-group) were recorded on the fifth and tenth days of follow-up and compared with those of the other 40 patients 40 patients who vitamin $D$ supplementation was not started because of high vitamin D levels (control-group).

Results: Of the 80 patients, 40 (50\%) were male and 40 (50\%) were female. The mean age of the patients was $72 \pm 10.8$ years. The mean vitamin D level of the case group was $11.6 \mathrm{ng} / \mathrm{ml}$. On the 10. day levels of the inflammatory markers C-Reactive Protein, Procalcitonin, D-Dimer, Ferritin, Interleukin-6 and Lactate Dehydrogenase were significantly lower and the lymphocyte count was significantly higher in the case group than in the control group. On the 5. day, the interleukin-6 level was significantly lower in the case group. Weaning was performed in nine and four patients in the case and control groups, respectively. There was no significant difference in mortality rates between the groups.
\end{abstract}

Conclusion: Vitamin-D supplementation can help reduce cytokine response. Recommended prophylactically or therapeutically at all stages of coronavirus disease.

Keywords: Elderly patients, COVID-19, cytokine release syndrome, intensive care units, vitamin D

\section{Öz}

Amaç: COVID-19 enfeksiyonunda klinik; asemptomatik durumdan, sitokin fırtınası ile karakterize ölümcül tabloya kadar değişen geniş bir yelpazede seyretmektedir. Bu makalede, tanı aldıktan sonra yoğun bakımda takibe başlanan geriatrik hasta grubunda $D$ vitamini desteğinin terapötik etkisi ve hastalık şiddeti üzerine potansiyel önemini vurgulamak istiyoruz.

Gereç ve Yöntem: Mart ve Haziran 2021 tarihleri arasında Yoğun Bakım Kliniğimizde takip edilen COVID-19 tanısı almış 65 yaş ve üstü 80 hastanın verileri retrospektif olarak incelendi. Serum $25(\mathrm{OH}) \mathrm{D}<30 \mathrm{ng} / \mathrm{mL}$ olan ve D vitamini desteği başlanan 40 hastanın, COVID-19 tanısı aldıktan sonra 5. ve 10. günlerdeki enflamatuar parametreleri ve klinik seyri kaydedilerek, Serum $25(\mathrm{OH}) \mathrm{D}>30 \mathrm{ng} / \mathrm{mL}$ olan bu nedenle D vitamini desteği başlanmamış olan kontrol grubunun verileri ile karşılaştıııldı.

Bulgular: 80 hastadan 40'ı (\%50) erkek ve 40' (\%50) kadın idi. Hastaların ortalama yaşı $72 \pm 10,8$ yıldı. Vaka grubunun ortalama D vitamini düzeyi 11,6 $\mathrm{ng} / \mathrm{mL}$ idi. 10. gün ölçümlerinde enflamatuar belirteçlerden CRP, Prokalsitonin, D-Dimer, Ferritin, IL-6, LDH değerlerinin kontrol grubuna göre anlamlı düşük seyrettiği $(P<0,05)$ ve lenfosit değerinin anlamlı yüksek seyrettiği gözlendi $(p=0,008)$. Beşinci gün ölçümlerinde IL-6 düzeyi vaka grubunda anlamlı olarak daha düşüktü. Vaka ve kontrol grubunda sırasıyla 9 ve 4 hastada weaning uygulandı. Gruplar arasında weaning ve mortalite oranları açısından istatistiksel olarak anlamlı bir fark görülmedi.

Sonuç: D vitamini tedavisinin, özellikle hipovitaminoz D'nin sık görüldüğü geriatrik hastalarda sitokin yanıtını azaltmada katkı sağlayabileceği makul görünmektedir. D vitamini takviyesi, coronavirüs hastalığının tüm aşamalarında profilaktik veya terapötik olarak önerilir

Anahtar Kelimeler: Geriatrik popülasyon, COVID-19, sitokin fırtınası, yoğun bakım üniteleri, D vitamini

Corresponding (iletişim): Yeliz BiLiR, Health Sciences University Kartal Dr. Lutfi Kirdar City Hospital, Department of Anesthesiology and Reanimasyon, Intensive Care Unit, Istanbul, Turkey

E-mail (E-posta): dryelizbilir@yahoo.com

Received (Geliş Tarihi): 03.09.2021Ａccepted (Kabul Tarihi): 09.12.2021 


\section{INTRODUCTION}

Coronaviruses are a large family of viruses that can infect animals and humans. The world is now battling the third largest coronavirus outbreak, following the Middle East respiratory syndrome (MERS) and severe acute respiratory syndrome (SARS) epidemics. This coronavirus has been officially named as severe acute respiratory syndrome coronavirus-2 (SARSCoV-2) by the World Health Organization (WHO) and the term coronavirus disease (COVID-19) has been used to describe the disease caused by this virus. The COVID-19 outbreak was declared a global health emergency on January 30,2020, and was recognized as a viral pandemic on March 11, 2020.[1]

The aging of the population is an important issue at present. Aging is considered a medical and social problem. The older population is more susceptible to severe coronavirus disease and has a higher mortality rate. A large number of patients hospitalized in intensive care units with a diagnosis of COVID-19 are aged over 65 years all over the world, including Turkey. ${ }^{[2,3]}$ The first COVID-19 case in Turkey, announced by the Ministry of Health on March 10, 2020, was an 89-yearold male patient. Considering that older individual stend to have at least one chronic disease, the older population is thought to be most affected by the pandemic and to have the highest mortality rate. Immuno supportive treatments have been shown to strengthen the immune system of older adults in intensive care units (ICUs) and reduce mortality and morbidity. ${ }^{[4]}$

Vitamin D plays a critical role in the immune system. It is an immunomodulatory hormone with anti-inflammatory and antimicrobial effects, in addition to anti-oxidant effects (by increasing glutathione reductase expression). ${ }^{[4,5]}$ It has been reported in some studies that vitamin $D$ deficiency may contribute to the development of viral diseases. ${ }^{[6]}$ Moreover, it is emphasized that if there is vitamin $D$ deficiency in COVID-19 patients, their sensitivity may increase in terms of complications and mortality due to infection..$^{[7]}$

The serum 25-hydroxyvitamin $D[25(\mathrm{OH}) \mathrm{D}]$ level stend to decrease with age. ${ }^{[8]}$ Vitamin $D$ deficiency is very common in the northern hemisphere because of low ultraviolet exposure, especially during winter months when the pandemic has been prevalent.

Vitamin $D$ has been thought to affect prognosis by suppressing the cytokine response through the downregulation of proinflammatory cytokines ${ }^{[9]}$ In severe COVID-19 patients, the main problem is the inappropriate inflammatory response; therefore, it is crucial to initiate anti-inflammatory therapies that alleviate the cytokine storm in the case of high interleukin (IL)-6 expression.

Vitamin $D$ polarizes the adaptive immune response from $T$ helper type 1 (Th1) to T helper type 2 (Th2) response. CD4 (+) $T$ cell production increases, and Th1 production decreases. Thus, the production of pro-inflammatory Th1 cytokines, such as tumor necrosis factor- $a$, interferon- $\gamma$, IL-6, IL-8, IL-12, and IL-17, is reduced. ${ }^{[10]}$ In addition, vitamin $D$ increases the expression of inflammatory cytokines by macrophages via the modulation of the innate immune response (macrophage, polymorphonuclear cell, monocyte and Toll-like receptor expression). ${ }^{[1]}$

The mechanism of COVID-19 starts with the attachment of SARS-CoV-2 to the angiotensin-converting enzyme 2 (ACE2) receptor. ${ }^{[12,13]}$ The virus gains entry into the cell and down regulates ACE-2. This causes excessive accumulation of angiotensin II. ${ }^{[14]}$ The high incidence of COVID-19 in the older population, particularly in men, may be associated with the low ACE-2 expression level. On the other hand, renin is a proteolytic enzyme and a positive regulator of angiotension II. Vitamin D is a powerful renin inhibitor. ${ }^{[14]}$

The serum 25(OH)D level is one of the most widely used biomarkers to detect vitamin $D$ deficiency. ${ }^{[15]} \mathrm{A}$ serum $25(\mathrm{OH})$ D level below $30 \mathrm{ng} / \mathrm{ml}$ is usually considered deficient. For certain patient groups, it is also advocated to maintain the serum 25(OH)D level above $40 \mathrm{ng} / \mathrm{ml}{ }^{[16]}$ Vitamin $D$ supplementation improves clinical outcomes in COVID-19 patients. ${ }^{[17]}$ As the potential benefits of high-dose oral vitamin $\mathrm{D}$ are much more than the theoretical risks, it is thought that the use of high-dose oral vitamin D will help reach vitamin D sufficiency quickly and thus contribute to the immune response. Therefore, the present study aimed to emphasize the therapeutic effect of vitamin D supplementation and its potential importance in reducing the disease severity in older adults who were followed up in the ICU after being diagnosed with COVID-19.

\section{MATERIAL AND METHOD}

This study was carried out in a city hospital that was actively operating during the pandemic period with 70 intensive care beds. Approval was obtained from the Institutional Ethics Committee [2020/514/182/18]. However, informed consent was not obtained due to the retrospective planning of the study. The study was conducted in accordance with the ethical principles stated in the Declaration of Helsinki, Good Medical Practice Guidelines and Good Laboratory Practice Guidelines.

The study sample consisted of 80 older adults ( $\geq 65$ years old). Patients ( 40 women and 40 men) admitted to the intensive care unit with the diagnosis of COVID-19 between March and July 2021 were included in the study. Antiviral treatment and supportive treatments were started according to the diagnostic and treatment criteria of the Turkish Scientific Committee. In our hospital, vitamin C supplementation is routinely started in all patients, and vitamin D replacement is given to patients with low vitamin $D$ levels.

The patients were divided into two groups. Patients whose with serum 25(OH) D levels below $30 \mathrm{ng} / \mathrm{ml}$ and who received vitamin $D$ supplementation were included in the case group $(n=40)$, while patients whose with serum $25(\mathrm{OH})$ $D$ levels above $30 \mathrm{ng} / \mathrm{ml}$ and who did not receive vitamin $D$ supplementation were included in the control group $(n=40)$. 
Patients with comorbidities that could cause death (such as progressive Stage-4 malignancy, pulmonary embolism, diabetic ketoacidosis, advanced chronic kidney disease, acute liver failure, pregnancy, and acute myocardial infarction) were excluded from the study. Patients included in the case group were given a loading dose of $50,000 \mathrm{IU}$ of vitamin D at the time of admission. A week later, a repeat dose of 50,000 IU was given once to increase vitamin $D$ levels in the body. The laboratory data and clinical course of the two groups were recorded and compared statistically on the fifth and tenth days after the ICU admission

The patients' files were retrospectively accessed from the electronic registration system of the hospital. The demographic data (age, gender, and presence of comorbidities), treatments received, oxygenation status, presence of mortality, weaning success, discharge status, length of ICU stay, COVID-19 positivity (assessed by polymerase chain reaction), vitamin $D$ levels, and laboratory data [ferritin, D-dimer, C-reactive protein (CRP), IL-6, lactate dehydrogenase (LDH), and procalcitonin levels and lymphocyte count]were recorded. The intubation or extubation status of the patients was stated during admission to the intensive care unit and during follow-up.

\section{RESULTS}

Eighty patients aged between 65 and 90 years $(72.69 \pm 10.87$ years) were included in the present study. In the case group, 21 patients were female (52.5\%) and 19 were male (47.5\%), while in the control group, 19 patients were female (47.5\%) and 21 were male (52.5\%). No significant difference was noted between the groups in terms of the hospitalization SOFA score, APACHE-II score, presence of comorbidities, and antiviral treatments used (Table 1). Vitamin D supplementation was given to 40 patients whose vitamin D levels were between 7 and $27 \mathrm{IU}$ (mean, $11 \pm 5 \mathrm{IU}$ ).

The IL-6 level, which is an important marker of cytokine storms and macrophage activation syndrome (MAS), was significantly lower in the case group than in the control group on the fifth day and on the tenth day ( $p=0.001$ and $p=0.001$, respectively). The measurements performed on the tenth day revealed that CRP, procalcitonin, D-dimer, ferritin, and LDH levels were significantly lower $(p<0.05)$ and the lymphocyte count was significantly higher $(p=0.008)$ in the case group than in the control group (Table 2).

No significant difference was observed between the two groups in terms of the mortality rate, length of ICU stay, hospitalization duration, and weaning success (Table $\mathbf{3}$ ).

\section{DISCUSSION}

The effect of vitamin D supplementation (which protects against SARS-CoV-2 infection) on cytokine storm development, mortality, and morbidity was retrospectively studied in patients hospitalized in the ICU after being diagnosed with COVID-19.
Table 1. Characteristics of subjects

\begin{tabular}{|c|c|c|c|}
\hline & $\begin{array}{c}\text { Control Group } \\
(n=40)\end{array}$ & $\begin{array}{c}\text { Case Group } \\
(n=40)\end{array}$ & $\mathbf{p}$ \\
\hline Age & $65 \pm 90(73.8)$ & $65 \pm 87(70.25)$ & 0.858 \\
\hline Gender & & & 0.655 \\
\hline 0 (Male) & $19(47.5 \%)$ & $21(52.5 \%)$ & \\
\hline 1 (Female) & $21(52.5 \%)$ & $19(47.5 \%)$ & \\
\hline DiabetesMellitus & $14(35.0 \%)$ & $15(37.5 \%)$ & 0.816 \\
\hline Coronary Artery Disease & $18(45.0 \%)$ & $10(25.0 \%)$ & 0.059 \\
\hline Hypertensıon & $24(60.0 \%)$ & $26(65.0 \%)$ & 0.644 \\
\hline Congestıve Heart Fallure & $9(22.5 \%)$ & $13(32.5 \%)$ & 0.316 \\
\hline $\begin{array}{l}\text { Chronic Obstructive } \\
\text { Pulmonary Disease }\end{array}$ & $5(12.5 \%)$ & $10(25.0 \%)$ & 0.149 \\
\hline Cerebro vascular Diseases & $12(30.0 \%)$ & $9(22.5 \%)$ & 0.445 \\
\hline Malignite & $5(22.7 \%)$ & $3(7.5 \%)$ & 0.087 \\
\hline Immun Plasma Treatment & $9(22.5 \%)$ & $9(22.5 \%)$ & 1.000 \\
\hline AntıVıral Treatment & $34(85.0 \%)$ & $34(85.0 \%)$ & 1.000 \\
\hline Tocilizumab Treatment & $8(20.0 \%)$ & $5(12.5 \%)$ & 0.361 \\
\hline Positive RT-PCR Test & $23(57.5 \%)$ & $19(47.5 \%)$ & 0.370 \\
\hline SOFA score & $5.78 \pm 1.37(6)$ & $5.73 \pm 1.72(5.5)$ & 0.764 \\
\hline APACHE-II score & $27.28 \pm 8.24$ & $26.0 \pm 9.16$ & 0.515 \\
\hline
\end{tabular}

Table 2. Measurement values of the groups

\begin{tabular}{|c|c|c|c|}
\hline & Control Group $(n=40)$ & Case Group $(n=40)$ & $\mathbf{P}$ \\
\hline P/F Admission & $132.90 \pm 31.89$ & $135.65 \pm 37.91$ & 0.726 \\
\hline P/F 2 Discharge & $153.5 \pm 62.96(126.5)$ & $187.09 \pm 89.01(210)$ & 0.251 \\
\hline CRP 1 & $92.55 \pm 145.42(63)$ & $93.63 \pm 76.88(72.9)$ & 0.456 \\
\hline CRP 2 & $141.66 \pm 82.50$ & $118.56 \pm 86.74$ & 0.232 \\
\hline CRP 3 & $196.97 \pm 128.81(187)$ & $80.14 \pm 76.46(58)$ & $0.001^{*}$ \\
\hline Dimer 1 & $4326.9 \pm 5565.4(2320)$ & $5073.0 \pm 7836.2(2235)$ & 0.546 \\
\hline Dimer 2 & $4574.5 \pm 4504.8(2955)$ & $3565.4 \pm 3666.8(2400)$ & 0.564 \\
\hline Dimer 3 & $5084.8 \pm 4957.2(3720)$ & $2269.9 \pm 2425.2(1140)$ & $0.005^{*}$ \\
\hline Ferritin 1 & $661.2 \pm 515.1(489)$ & $430.8 \pm 472.8(228)$ & $0.028^{*}$ \\
\hline Ferritin 2 & $428.5 \pm 617.4(813)$ & $531.4 \pm 491.8(326)$ & 0.061 \\
\hline Ferritin 3 & $777.4 \pm 533.8$ (739.5) & $430.7 \pm 395.3(381.5)$ & $0.013^{*}$ \\
\hline IL6 1 & $149.5 \pm 151.5(96.85)$ & $242.1 \pm 842.7(42)$ & $0.016^{*}$ \\
\hline IL6 2 & $730.9 \pm 2022.9(147.5)$ & $115.6 \pm 129.6(66)$ & $0.001^{*}$ \\
\hline IL6 3 & $1234.5 \pm 2445.9(363)$ & $141.9 \pm 257.8(45)$ & $0.001^{*}$ \\
\hline LDH 1 & $409.1 \pm 236.5(356)$ & $478.9 \pm 432.4(311)$ & 0.519 \\
\hline LDH 2 & $456.2 \pm 283.3(408.5)$ & $482.1 \pm 464.3(367)$ & 0.342 \\
\hline LDH 3 & $417.1 \pm 191.3$ (410.5) & $324.5 \pm 200.9$ (249) & $0.042^{*}$ \\
\hline PRC 1 & $1.48 \pm 2.67(0.43)$ & $2.34 \pm 7.12(0.4)$ & 0.983 \\
\hline PRC 2 & $4.05 \pm 7.58(1.1)$ & $2.03 \pm 3.14(0.75)$ & 0.265 \\
\hline PRC 3 & $3.89 \pm 5.71(1.6)$ & $2.43 \pm 7.36(0.25)$ & $0.010^{*}$ \\
\hline Lenfosit 1 & $1128.2 \pm 1107.4(1000)$ & $950.0 \pm 493.6(850)$ & 0.381 \\
\hline Lenfosit 2 & $744.7 \pm 383.2(600)$ & $902.6 \pm 423.3(800)$ & 0.110 \\
\hline Lenfosit 3 & $812.5 \pm 499.5(650)$ & $1165.5 \pm 530.7(1200)$ & $0.008^{*}$ \\
\hline
\end{tabular}

\begin{tabular}{|c|c|c|c|}
\hline & $\begin{array}{c}\text { Control Group } \\
(n=40)\end{array}$ & $\begin{array}{c}\text { Case Group } \\
(n=40)\end{array}$ & $\mathbf{P}$ \\
\hline İntubated AdmissionTo İcu & & & 0.81 \\
\hline 0 & $27(67.5 \%)$ & $26(65.0 \%)$ & \\
\hline 1 & $13(32.5 \%)$ & $14(35.0 \%)$ & \\
\hline Being İntubated Stay İn İcu & $30(75 \%)$ & $29(72.5 \%)$ & 0.79 \\
\hline Weaning & $4(12.9 \%)$ & $9(29.0 \%)$ & 0.11 \\
\hline Length of ICU stay (days) & $13.13 \pm 8.37(11)$ & $11.78 \pm 7.42(10)$ & 0.44 \\
\hline Hospitalization duration (days) & $15.30 \pm 9.83(11)$ & $14.85 \pm 9.06(12.5)$ & 0.98 \\
\hline Death & & & \\
\hline Mortality (-) & $14(35.0 \%)$ & $20(50.0 \%)$ & 0.17 \\
\hline Mortality (+) & $26(65.0 \%)$ & $20(50.0 \%)$ & \\
\hline
\end{tabular}


Many recent studies have revealed that vitamin D can have immunomodulatory and anti-inflammatory effects, thereby reducing morbidity and mortality in COVID-19 patients. ${ }^{[18,19]}$

In elderly patients, the risk of hypovitaminosis is higher due to the decreased time spent outdoors, increased adiposity, decreased vitamin $D$ synthesis in the skin, decreased vitamin D absorption in the intestine, decreased 7-dehydrocholesterol level in the skin, and use of multidrug treatments. ${ }^{[20]}$ Considering that the mortality rates increase with age, the importance of each intervention targeting the afore mentioned issues increases.

In their study conducted to determine the relationship between vitamin D levels and COVID-19 in advanced age Parkinson's patients, Hribar et al. found that daily vitamin D supplementation has a positive effect on the severity of COVID-19 and the disease course in older adults. It has been emphasized that vitamin $D$ supplementation can be preferred, especially because it is cheap and reliable. ${ }^{[18]}$ As a result of the study of Baktash et al. with 105 patients, it was observed that patients with vitamin D deficiency had higher peak D-dimer levels and a need for NIV support, but there was no difference in mortality between the groups. ${ }^{[2]]}$ Moreover, Alipio et al. demonstrated a significant correlation between serum 25(OH)D levels and clinical results $(p<0.001)$. In their study, serum 25(OH)D levels were found to be the lowest in critical cases and the highest in mild cases. As a result, they stated that an increase in serum $25(\mathrm{OH}) \mathrm{D}$ levels in the body can improve clinical outcomes. ${ }^{[17]}$ In the present study, we found that although the demographic data of the groups were similar, the clinic in the case group receiving vitamin $D$ supplementation was not as noisy as in the control group. For example, in the case group, nine patients were moved out of the intensive care unit by weaning. In the control group, weaning could be performed in only four patients. We can explain this clinical success with suppressed abnormal immune response. The Pao2/Fio2 ratio in the case group was higher than the control group, but this was not statistically significant. We can attribute this situation to the fact that the COVID-19 disease is a disease that progresses with very serious desaturation in ICU follow-up.

In a recent study, Grant et al. mentioned that supplementation with more than one micronutrient having immunosupportive roles can modulate the immune function and reduce the risk of infection. In particular, they stated that supplementation with micronutrients with the strongest evidence for immune support, namely vitamin C, vitamin Dandzinc, is recommended. They emphasized that vitamin $D$ supplementation could decrease mortality in influenza and COVID-19 patients. ${ }^{[22]}$ In the present study, 26 patients died in the control group, while 20 patients died in the case group; the difference between the groups was not significant. We can attribute this numerical difference to the development of more cytokine storms in the control group. The development of cytokine storm is one of the most important causes of mortality in COVID-19 patients.
Rhodes et al. revealed that sunny countries, such as Spain and Italy, have a surprisingly high prevalence of vitamin D deficiency. Moreover, these countries have the highest rates of infection and death due to COVID-19 in Europe. They reported that the vitamin $\mathrm{D}$ level correlates with the severity of the immune response to COVID-19. ${ }^{[23]}$

Panarese stated that the effect of vitamin D on COVID-19 is due to the suppression of cytokine response and reduction of the severity and risk of acute respiratory distress syndrome and therefore recommended regular vitamin $D$ supplements. ${ }^{[24]}$ In a meta-analysis of 11,321 patients, Martineau et al. emphasized that vitamin $D$ supplementation could positively change the inflammatory response and should therefore be recommended if the inflammatory response needs to be improved. ${ }^{[19]}$ However, Autier et al. reviewed the publications and meta-analyses on vitamin $D$ supplementation between 2013 and 2017 and concluded that 10-20 $\mu \mathrm{g}$ of vitamin D per day can reduce all-cause mortality; however, it does not have a significant effect on the biological markers of systemic inflammation. ${ }^{[25]}$ However Wang et al. showed that vitamin d supplementation is a cost-effective approach to reduce hospitalization and/or death rates in patients newly diagnosed with COVID-19 and to prevent infection among close household contacts. ${ }^{[26]}$

In the literature, there are heterogeneous results about vitamin D supplementation. In the present study, the cytokine response on the tenth day was found to be significantly lower in the case group than in the control group. Moreover, CRP, procalcitonin, D-dimer, ferritin, and LDH levels were significantly lower and the lymphocyte count was significantly higher in the case group than in the control group. In addition, the clinical course of the patients was more benign in the case group. Although the difference in the Pao2/Fio2 ratio was not significant, it increased to a greater extent in the case group. While the number of patients who developed MAS and received tocilizumab was five in the case group, it was eight in the control group. Thus, the presence of an abnormal inflammatory response was significantly higher in the control group.

\section{CONCLUSION}

The present study revealed that vitamin D supplementation in the older population can regulate the immune system and affect the course of COVID-19 by positively contributing to the inflammatory response, clinical course, and weaning. In conclusion, vitamin D supplementation, which is safe, can be recommended as a prophylactic or therapeutic option at every stage of COVID-19.

\section{ETHICAL DECLARATIONS}

Ethics Committee Approval: Health Sciences University KartalDr.LutfiKirdar City Hospital Institutional Ethics Committee approval: [2020/514/182/18] 
Informed Consent: Because the study was designed retrospectively, no written informed consent form was obtained from patients.

\section{Referee Evaluation Process: Externally peer-reviewed.}

Conflict of Interest Statement: The authors have no conflicts of interest to declare.

Financial Disclosure: The authors declared that this study has received no financial support.

Author Contributions: All of the authors declare that they have all participated in the design, execution, and analysis of the paper, and that they have approved the final version.

\section{REFERENCES}

1. World Health Organization. (2020). Coronavirusdisease 2019 (COVID19):situationreport, 82.

2. D'Adamo H, Yoshikawa T, Ouslander JG. Coronavirus disease 2019 in geriatrics and long-term care:the ABCDs of COVID-19. J Am Geriatr Soc 2020;68(5):912-17.

3. Duru S. Yaşlı Hastalarda COVID-19. diğer:Göğüs Hastalıkları Uzmanlarının Bilmesi Gerekenler'başlıklı ek sayısında derlemeyi. 2020;128.

4. Beard JA, Bearden A, Striker R. Vitamin D and the anti-viral state. J Clin Virol 2011;50(3):194-200.

5. Greiller $\mathrm{CL}$, Martineau AR. Modulation of the immuneresponse to respiratory viruses by vitamin D. Nutrients 2015;7(6):4240-70.

6. Teymoori-Rad M, Shokri F, Salimi V, et al. The inter play between vitamin D and viral infections. Rev Med Virol 2019;29(2):e2032.

7. Trovas G, Tournis S. Vitamin D and COVID-19. Hormones (Athens) 2021;20:207-8.

8. Vásárhelyi B, Sátori A, Olajos F, et al. Low vitamin D level samong patients at Semmelweis University:retrospective analysis during a one-year period. Orv Hetil 2011;52(32):1272-7.

9. Conti P, Ronconi G, Caraffa A, et al. Induction of pro-inflammatorycytokines (IL-1 andIL-6) and lung inflammation by Coronavirus-19 (COVID-19 or SARS-CoV-2):anti-inflammatory strategies. J Biol Regul Homeost Agents 2020;34(2):327-31.

10. Ardizzone S, Cassinotti A, Trabattoni D, et al. Immunomodulatoryeffects of 1,25-dihydroxyvitamin $\mathrm{D} 3$ on $\mathrm{TH} 1 / \mathrm{TH} 2$ cytokines in inflammatory bowel disease:an in vitro study. Int J Immunopathol Pharmacol 2009;22:63-71.

11. Zabetakis I, Lordan R, Norton C, et al. COVID-19:The Inflammation Link and the Role of Nutrition in Potential Mitigation. Nutrients 2020;12(5):1466.

12. Yan $R$, Zhang $Y$, Li Y, et al. Structural basis for there cognition of SARSCoV-2 by full-length human ACE2. Science 2020;367(6485):1444-8.

13. Gheblawi M, Wang K, Viveiros A, et al. Angiotensin-Converting Enzyme 2:SARS-CoV-2 Receptorand Regulator of the Renin-Angiotensin System:Celebrating the 20th Anniversary of the Discovery of ACE2. Circ Res 2020;126(10):1456-74.

14. LiYC, Qiao G, Uskokovic M, et al. Vitamin D:a negative endocrine regulator of the renin-angiotensinsystemandbloodpressure. J Steroid Biochem Mol Biol. 2004;(1-5):387-92.

15. Binkley N, Ramamurthy R, Krueger D. Low vitamin D status:definition, prevalence, consequences, andcorrection. Endocrinol Metab Clin North Am 2010;39(2):287-301.

16. Thomas MK, Lloyd-Jones DM, Thadhani Rl, et al. Hypovitaminosis D in medical in patients. N Engl J Med 1998;338(12):777-83.

17. Alıpı M. Vitamin D Supplementation Could Possibly Improve Clinical Outcomes of Patients Infected with Coronavirus-2019 (COVID-19). Available at SSRN 3571484, 2020.

18. Hribar CA, Cobbold PH, Church FC. Potential Role of Vitamin D in the Elderly to Resist COVID-19 and to Slow Progression of Parkinson's Disease. Brain Sci. 2020;10(5):284.

19. Martineau AR, Jolliffe DA, Hooper RL, et al. Vitamin D supplementation to prevent acute respiratory tract infections:systematic review and metaanalysis of individual participant data. BMJ 2017;356:16583
20. Boucher BJ. Theproblems of vitamin d insufficiency in older people. Aging Dis. 2012;3(4):313-29.

21. Baktash V, Hosack T, Patel N, et al. Vitamin D status and outcomes for hospitalised older patients with COVID-19. Postgrad Med J. 2021;97(1149):442-7

22. Grant WB, Baggerly CA, Lahore H. Reply:"Vitamin D Supplementation in Influenza and COVID-19 Infections. Comment on:Evidence That Vitamin D Supplementation Could Reduce Risk of Influenza and COVID-19 Infections and Deaths Nutrients 2020, 12(4), 988". Nutrients 2020;12(6):16-20.

23. Rhodes JM, Subramanian S, Laird E, et al. Editorial:low population mortality from COVID-19 in countriessouth of latitude 35 degrees North supports vitamin $D$ as a factor determining severity. Aliment Pharmacol Ther. 2020;51(12):1434-7.

24. Panarese A, Shahini E. Letter:Covid-19, and vitamin D. Aliment Pharmacol Ther. 2020;51(10):993-5

25. Autier $P$, Mullie $P$, Macacu A, et al. Effect of vitamin D supplementation on non-skeletaldisorders:a systematic review of meta-analyses and randomised trials. Lancet Diabetes Endocrinol 2017;5(12):986-1004.

26. Wang R, De Gruttola V, Lei Q, et al. The vitamin D for COVID-19 (VIVID) trial:A pragmatic cluster-randomized design. Contemp Clin Trials. 2021;100:106-76. 